\title{
Using a Metamemory Based Program in Developing EFL Secondary School Students' Creative Reading Skills
}

\author{
By
}

\section{Shaimaa Galal El Sayed Ebrahim}

A Ph.D. researcher

Department of Curricula and

Methodolgy

Faculty of Education. Zagazig

University

استخدام برنامـج قائم على ما وراء الذاكرة فى تنمية مهارات القراءة الإبداعية

باللغة الإنجليزية كلغة أجنبية لدى طلاب المرحلة الثانوية

الملخص :هدفت الدراسة الحالية إلى الاستقصاء عن استخدام برنامـج قائم على ما

وراء الذاكرة فى تنمية مهارات القراءة الإبداعية باللغة الانجليزيـة كلغة أجنبية لدى طلاب

المرحلة الثانوية ـ وتكونت عينة الدراسة من سبعين طالبـة فى الصف الثانى الثانوى، حيث تم

تقسيهمه إلى مجموعة تجريبية (خمس وثلاثين طالبة) ومجموعة ضابطة (خمس وثلاثين

طالبة). وقد قامت الباحثة بتصميه اختبار للقراءة الإبداعية وكذلك برنامج قائم على ما

وراء الذاكرة لتتمية مهارات القراءة الإبداعية باللغة الإنجليزية للمجمموعة التجريبية ، وتم

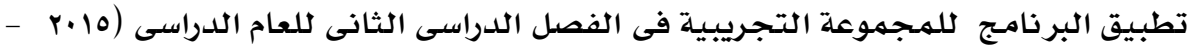

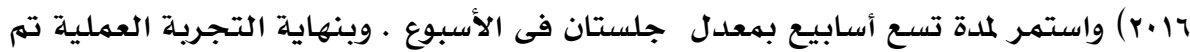

توزيع إختبار القراءة الإبداعية لكل من المجموعتين الضابطة والتجريبية لمعرفة مدىى

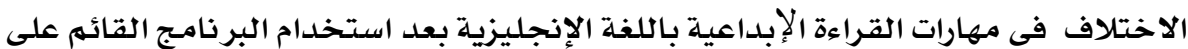
ما وراء الذاكرة. ولقد أوضحت النتائج أن البرنامـج القائم على ما وراء الذاكرة فعال فى تنمية مهارات القراءة الإبداعية باللغة الإنجليزية لطلاب المجموعة التجريبية.

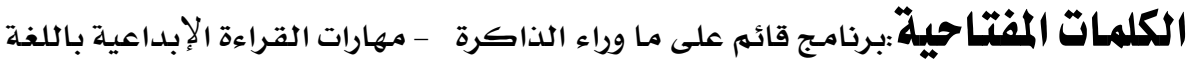
الإنجليزية

\section{Abstract}

The present study aimed at investigating the using of a metamemory based program in developing EFL secondary school students' creative reading skills. Seventy second-year secondary school students were the participants in this study. 
They were assigned randomly to an experimental group (thirty five) and a control group (thirty five). An EFL creative reading skill test was used as an instrument in this study. A metamemory based program was designed by the researcher to develop the experimental group students' creative reading skills. The program was conducted in the second term of the academic year $(2015 / 2016)$ and lasted for nine weeks, two sessions a week. On the other hand, the students of the control group received the regular instruction. By the end of the experimentation, the creative reading test was administered to the control and the experimental groups to identify the difference of the metamemory program in developing the EFL creative reading skills. The results of the study revealed that the meta-memory based program was efficient in developing the experimental group's EFL creative reading skills.

Key words: meta-memory based program, EFL creative reading skills

\section{Introduction}

Nowadays, the ability to read in English as a foreign language is necessary. Not only mastering the basic reading skills is important, but also the creative ones. That is recommended by the Ministry of Education Directives (2015/2016) for English Language Syllabus at the Secondary Stage while stressing the importance of developing the students' creativity. Holden $(2004)^{(7)}$ confirmed that reading should not be a passive skill where the reader absorbs the writer's words like a sponge. Reading in itself is a creative process. While reading creatively, no two people read the same text in the same way. Everyone brings his/her own set of experiences and viewpoints. When people read creatively; they put themselves in the places and situations that are described in the text, they play with meanings and act out scenes in their heads. Moorman and Ram $\left(1994^{(10)}\right.$ indicated that creative reading is a part of all successful reading experiences. In order to creatively read, a person should be a capable reader at a number of levels, from simple decoding of words to building of complex mental worlds. Although 
creativity is recognized as a crucial issue in reading, it has been disregarded.

Metamemory is approved to be one of the effective methods for developing EFL creative reading skills. First, Amiri and Ghiassi $\left(2012^{)(2)}\right.$ indicated that metamemory is one of the subcategories of metacognition. Originally, the term metamemory was first used by Flavell in 1977 to refer to a person's knowledge about the contents and regulation of memory. Metamemory plays an important role in planning, strategy selection, and evaluation of performance. Karably and Zabrucky $\left(2009^{(8)}\right.$ also believed that metamemory involves the ability to monitor and regulate one's memory. Memory monitoring involves an individual's ability to judge how well he/she is performing on a memory task as well as the ability to use strategies to improve performance. Numminen $\left(2002^{(13)}\right.$ indicated that while reading a text, short-term memory affects the ability to receive and maintain information in the mind at a given moment, while long-term memory affects the ability to understand the vocabulary in a text and references between concepts. Amiri and Ghiassi $\left(2012^{)(2)}\right.$ reported that metamemory plays a role in EFL reading proficiency since metamemory requires students to think reflectively about their own thinking in relation to a given reading passage. Metamemory activities can really change EFL learners be to active ones collaborating with their teacher in the process of comprehending a reading passage.

\section{Context of the problem}

Being a teacher of English, the researcher has noticed that the sufficient interest was not given to EFL creative reading skills despite their great importance. Teachers concentrate only on teaching the prescribed texts.

To make sure that there is a problem, the researcher has reviewed previous studies related to the EFL creative reading skills in the context of the Arab countries, especially in Egypt as follows: Moharam $\left(1997^{(10)}\right.$, Masoud $\left(2014^{(9)}\right.$, and Abdul Latif $\left(2006^{(1)}\right.$ confirmed that EFL students in secondary schools and colleges in Egypt face a lot of difficulties while reading creatively. The researcher also conducted a pilot study in which 
a creative reading test was administered to the EFL second-year secondary school students. The results of the pilot study disclosed that the level of the students was low and they were really inefficient in EFL creative reading

\section{Statement of the problem}

The problem of this study can be stated in the poor performance of the second-year secondary stage students in the EFL creative reading skills; therefore this study is an attempt to develop the EFL students' creative reading skills using a metamemory based program.

\section{Questions of the study}

In order to tackle this problem, the present study was an attempt to address the following main question:

"What is usage of the metamemory based- program in developing EFL second-year secondary school students' creative reading skills?"

The following sub- questions have been derived

1- What are the necessary creative reading skills needed for EFL second-year secondary stage students?

2- What are the actual levels of the EFL second-year secondary stage students in the creative reading skills?

3- What is the framework of the metamemory based program for developing EFL second-year secondary stage students' creative reading skills?

\section{Aims of the study}

This study aimed at:

1- Developing the necessary creative reading skills of the EFL second-year secondary school students.

2- Designing a metamemory based- program for developing EFL second-year secondary stage students' creative reading skills.

\section{Significance of the study}

This study was hoped to be of significance to:

1- The EFL second-year secondary school students: It can give those students a chance to develop their creative reading skills. 
2- EFL teachers of English: This study can help those teachers to understand how to adopt the metamemory activities for improving EFL creative reading skills.

3- Curriculum developers and designers: This study can provide a model of metamemory based program to help in the instruction of EFL creative reading skills.

4- EFL researchers: This study can pave the way for other researchers to conduct further studies on the metamemory activities in the EFL context.

\section{Delimitations of the study}

The study was delimited to:

1-The participants were secondary stage students in a public and rural school. That is because students in these schools are not trained well to read creatively in English.

2-The study was delimited to using one instrument which is an EFL creative reading test.

3-Developing some EFL creative reading skills which were approved by the jury members to be suitable to the participants.

\section{Procedures of the study}

The current study adopted the following procedures:

1- Surveying literature and previous studies related to metamemory and EFL creative reading skills.

2- Preparing a list of EFL creative reading skills and consulting a number of experts to select the appropriate ones.

3- Constructing the pre-posttest of creative reading and submitting it to the jury members to identify its validity

4- Administering the EFL creative reading test to both groups to identify the students' real standard concerning the identified EFL creative reading skills.

5- Designing the metamemory based program; intended to develop the EFL students' creative reading skills.

6- Implementing the metamemory based program to the experimental group by the researcher; aiming at developing their EFL creative reading skills; while the control group received the regular instruction. 
7- Administering the EFL creative reading test to both groups to investigate using the metamemory based program in developing the EFL creative reading skills.

8- Comparing the results of the control to experimental groups concerning the post administrations of the test and then analyzing them statistically.

9- Comparing the results of the pre to post administrations of the experimental group and analyzing them statistically.

10 - Interpreting the results and discussing them.

11- Providing conclusions, recommendations and suggestions.

\section{Definition of terms}

\section{Metamemory}

Amiri and Ghiassi $\left(2012^{(2)}\right.$ referred to metamemory as one of the subcategories of metacognition. Baker(1989) cited in Amiri and Ghiassi (2012) defined metamemory as being an active process of being aware of one's cognitive state with the ability to monitor production while it is taking place, make appropriate adjustments and make self evaluation of learning after the language activity is completed.

Operationally the metamemory in the present study can be defined as being "activities which enable EFL students to be aware of their memory system and different learning activities for improving their ability to read creatively in English"

\section{EFL creative reading}

Abdul Latif $\left(2006^{(1)}\right.$ defined creative reading as being the reader's ability to think of what he reads, go beyond the text, regard the missed parts and gaps in the information, synthesize information, add thoughts to a reading selection and suggest a certain conclusion.

Operationally creative reading can be defined as being "the ability to personalize natural phenomena by using as many personal qualities as possible, mention all the characteristics of someone to express opinions, suggest different titles for a story, produce various questions about information that is not directly mentioned in the text, thinking reflectively to generate more ideas for interest or clarity, imagine herself a character in a 
story to enhance the ideas, suggest new ends to a story, and give new strange names to characters of a story.

\section{Review of literature}

\section{Creative reading process or stages:}

Moharam $\left(1997^{(10)}\right.$ stated that creative reading is one of the highest processes that comes after literal and critical reading. Scaife (2015) and Ada (2003) cited in Rodriguez (2012)(14) explained that there are four phases of creative reading process. All phases act in a connected way as follows:

1- Descriptive phase: In this initial moment, a reader understands the content of the text. The teacher describes the new content. What? When? Where? Who? Why are questions asked by the reader and answered by the text.

2- Personal interpretation phase: a reader produces responses to the text with feelings based on his/her real life experiences. The type of questions that guide the dialogue in this phase would be of the nature of :( Who do I know that has experienced something similar? How has my own experience differed? Have you felt something like the author describes?

3- Critical / anti-bias phase: a reader engages in critical reflection. The type of questions that guide the dialogue in this phase would be of the nature of (Is this moral or appropriate? Who benefits (suffers) from these conditions? Is there a point the author tries to prove?

4- Creative phase: a reader is moving to action by the text. The type of questions to guide the dialogue in this is :( What can you do in a situation like the one in the text? In which ways would you act differently now?

\section{Characteristics of a creative reader:}

Masoud $\left(2014^{(9)}\right.$ indicated that a creative reader devotes his/her energy to actively construct relationships between ideas. These connections are not made explicitly by the writer. Readers think how the author's ideas might work in another context. When readers read and respond to what they read in this way, they turn the action of reading into a creative process which helps them develop new ways of thinking about, responding to, and understanding the world. Arts Council $\left(2009^{(3)}\right.$ described 
the creative reader as being the one who enters the world of the book, imagines the scene, becomes one of the characters and creates his/her own scene and characters. In creative reading activities, everyone reads and interprets the piece in his/her own way. That means there is no definitive understanding of the work. A reader is not creative when he/she merely digests the piece of writing in that kind of a box of chocolate.

\section{The importance of developing creative reading}

Moorman and Ram $\left(1994^{(12)}\right.$ indicated that creative reading is a part of all successful reading experiences. Although creativity is recognized as a central and crucial issue in reading, it has been disregarded. Any theory which overlooks this will be insufficient. To Holden $(2004)^{(7)}$, young people need to be equipped with high-level reading skills to meet the challenges of the twenty- first- century job market. Basic literacy is not enough. Readers must be able to analyze, interpret and synthesize. Reading in itself is a creative process. Knowledge is gained from reading creatively and also emotional depth and subtlety of response can be acquired. Rodirguez $\left(2012^{)(14)}\right.$ stressed the importance of developing creative reading skills in EFL classrooms. It was justified that creative reading activities affect EFL learners' empowerment, engagement, motivation, independent reflection and higher-order thinking. Creative reading skills enable students to explore material and understand it in more profound manner. Holden $(2004)^{(7)}$ claimed that the question today is not whether or not people can read, but how well they can read. To read well, a reader must be creative. Creative reading certainly helps students explore the world and be enriched educationally and emotionally. What a creative reader starts with is not what he/she ends with. Arts Council $\left(2009^{(3)}\right.$ indicated that creative reading is a rewarding experience because the reader is asked to engage with the work in a different way rather than passively taking in information.

\section{The metamemory activities}

Van Blerkom $\left(2009^{(18)}\right.$ stressed the importance of adopting memory activities for enabling students to retrieve ideas from their memory such as 
1- Repetition and practice enable students to retrieve ideas from their memory. In order to master something, people have to practice repeatedly.

2- Acronyms: words that are made up of the first letters of other words such as FBI. For example, the three branches of government are Executive, Legislative, and Judicial. Thinking about this acronym (JEL) will help students remember any list.

3- Acrostics: Acrostics is a sentence made up of words beginning with the first letters of other words. For remembering National Aeronautics and Space Administration, one could remember the sentence No Astronaut Stays Around. $\mathrm{N}$ in "No" stands for National, A stands for Aeronautic, S in stands for Space, and A stands for Administration.

Tran $\left(2013^{(17)}\right.$ provided some other activities to improve memory retention as follows: 1-Use Association to remember facts: To use association effectively, a student can create an image in his/her mind to help him/her remember an image. 2Touch, Hear and See It: The more senses a student involves when he/she needs to encode memory, the more strong a memory it becomes. 3-Organize It: By carefully organizing what it is a students has to memorize, he/she helps the brain better encode the information in the first place. 4-Visualize: a student should try to imagine himself/herself in the place he/she is reading about in order to remember what is being read. 5- Say it out loud: This is the easiest of all methods for remembering everything.

\section{The relationship between memory and creativity}

To Sawyer $\left(2013^{(15),}\right.$ some people probably think that memory is the exact opposite of creativity because things that persons memorize already exist, they are not new. And creativity is all about a new idea that didn't exist before. But the reality is great creativity is based on great memory. New ideas do not just appear out of air, they are built on existing ideas people have stored in memory over the years. If people do not remember all of this raw material, the mind will not be able to generate creative ones. Dachis $\left(2012^{)(5)}\right.$ agreed that memory has an effect 
on the types of ideas one can generate. When anyone tries to come up with new ideas, he/ she almost always starts with the familiar. People with low working memory capacities just stick with that familiar ones. People with high working memory capacities, however, start to depart from the usual and begin to look outside of what they already know. Christensen $\left(2013^{(4)}\right.$ concluded that Without memory, creativity will be the equivalent of trying to browse the internet without turning the computer on first.

\section{Using metamemory activities for developing creative reading skills}

Montgomery $\left(2003^{(11)}\right.$ explained that problems with comprehension while reading are associated with students' deficit working memory functioning. Shu-Chi and Tun-whei $\left(2009^{(16)}\right.$ indicated that training to use memory operations encourages EFL students to improve reading comprehension and develop their critical thinking skills. Word association encourages students to think of the relationship between what they already know and new words they are going to learn which resulted in a considerable improvement in EFL students' reading proficiency. Gaultney $\left(1992^{)(6)}\right.$ assured that metamemory steps enabled readers to activate schema which are then used to facilitate memorization of new material. Poor readers often do not utilize their existing knowledge to process new information. Adopting the metamemory activities encourage readers to ask "why" question in response to facts in the text consequently readers have greater chances for free recall. Salman (2011) confirmed that there is a strong relationship between metamemory activities and creativity while reading. Metamemory activities enable students to store, organize, analyze and criticize information while reading. These procedures help students activate this information in various learning situations.

\section{Study hypotheses}

1-There is a statistically significant difference between the mean scores of the experimental group, taught through the metamemory based program, and the control group, taught in 
the traditional way, in their performance of the post EFL creative reading test as a whole and its sub-skills, in favor of the experimental group.

2- There is a statistically significant difference between the mean scores of the experimental group in their performance of the pre and post administrations of the EFL creative reading test as a whole and its sub skills in favor of the post administration.

\section{Methodology}

\section{1-Participants of the study}

The participants of the study were second year secondary stage students in a rural area. The researcher chose these students for many reasons. First these students came from a rural area. The majority of them did not master the English creative skill. The secondary stage was chosen because it is a transitional period between basic education and college education. It is the best period to enable these students to develop their creative skills to be prepared to meet the modern educational and vocational needs. The participants were chosen from two classes. Every class has thirty five students. Two classes from Bani Shebl Secondary School represented the control and the experimental groups. To make sure that both groups were of the same level at the beginning of the experimentation, an EFL creative reading test was pre-administered to both groups. Then Independent Sample Test was employed to find out any statistical difference. The results of the independent sample test were as follows:

\begin{tabular}{|l|c|c|c|c|c|c|}
\hline \multicolumn{1}{|c|}{ The group } & $\begin{array}{c}\text { The } \\
\text { creative } \\
\text { reading }\end{array}$ & $\mathbf{N}$ & Mean & $\begin{array}{c}\text { Std. } \\
\text { deviation }\end{array}$ & T value & Sig. \\
\hline \multirow{2}{*}{$\begin{array}{l}\text { Experimental } \\
\text { group }\end{array}$} & \multirow{2}{*}{ Fluency } & 35 & 1.571 & .65 & \multirow{2}{*}{.197} & .2 \\
\cline { 1 - 3 } Control group & & 35 & 1.600 & .55 & & \\
\cline { 1 - 4 } $\begin{array}{l}\text { Experime-ntal } \\
\text { group }\end{array}$ & \multirow{2}{*}{ Flexibility } & 35 & 1.628 & .68 & \multirow{2}{*}{.368} & .4 \\
\cline { 1 - 4 } Control group & 35 & 1.571 & .60 & & \\
\hline \hline
\end{tabular}




\begin{tabular}{|c|c|c|c|c|c|c|}
\hline The group & $\begin{array}{l}\text { The } \\
\text { creative } \\
\text { reading }\end{array}$ & $\mathbf{N}$ & Mean & $\begin{array}{c}\text { Std. } \\
\text { deviation }\end{array}$ & T value & Sig. \\
\hline $\begin{array}{l}\text { Experimental } \\
\text { group }\end{array}$ & \multirow[t]{2}{*}{ elaboration } & 35 & 1.57 & .60 & \multirow[t]{2}{*}{.196} & \multirow[t]{2}{*}{.9} \\
\hline Control group & & 35 & 1.54 & .61 & & \\
\hline $\begin{array}{l}\text { Experimental } \\
\text { group }\end{array}$ & \multirow[t]{2}{*}{ Originality } & 35 & 1.51 & .56 & \multirow[t]{2}{*}{1.04} & \multirow[t]{2}{*}{.5} \\
\hline Control group & & 35 & 1.68 & .79 & & \\
\hline $\begin{array}{l}\text { Experimental } \\
\text { group }\end{array}$ & \multirow[t]{2}{*}{ Total } & 35 & 6.314 & 1.69 & \multirow[t]{2}{*}{.72} & \multirow[t]{2}{*}{.9} \\
\hline Control group & & 35 & 6.342 & 1.643 & & \\
\hline
\end{tabular}

The above table shows that the two groups were of the same level at the beginning of the experimentation. Thus any possible improvement after the experimentation would be attributed only to using the meta-memory based program.

\section{2-An instrument of the study}

To implement the suggested program, an EFL creative reading test was designed. To design the creative reading test, an EFL creative reading questionnaire was a pre- requisite. To grade the EFL creative reading test, an EFL creative reading rubric was a post requisite as follows:

\section{A-The EFL creative reading skills questionnaire}

\section{1- Purpose of the creative reading questionnaire}

The questionnaire was designed to determine the most important creative reading skills necessary for secondary school students

\section{2- Source of the creative reading skills questionnaire}

The items of the creative reading skills included in the questionnaire were adopted from: (a-the directives of the Ministry of Education for the school Year 2015/2016, bStudent's book, Hello English for second year of secondary stage and the teacher's guide for that book, c- Surveying literature and relevant studies concerned with developing EFL creative reading skills such as Masoud (2014), and Abdul Latif (2006) 


\section{3- Validity of the creative reading skills questionnaire.}

The questionnaire was submitted to a panel of jury who were specialists in the field of EFL teaching. Those jury members were requested to determine the suitability of the items of the questionnaire for secondary school students, and determine the degree of importance of each item. The questionnaire was considered valid.

\section{4- Content of the creative reading skills questionnaire}

At first the creative reading skills questionnaire included twelve creative reading skills. After analyzing the jury responses, the researcher selected the skills that were agreed upon for at least $75 \%$ by the jury members. Four skills were deleted as follows: "Generating as many sentences as possible related semantically to given words" was omitted because it is believed to be more related to the creative writing skill. "Suggesting multiple solutions for a specific problem" was given less importance. Concerning the elaboration skill "changing the content of a reading selection by adding information to this text" can be merged under the skill "suggesting new ends or conclusions for a story" to be one skill. "Telling a story using vocabulary mentioned in a text" was omitted because it was believed to be difficult for secondary school students in public schools to master this skill. Therefore eight skills were selected to be developed. (Appendix 1)

\section{B-The EFL creative reading test 1- Purpose of the creative reading test}

The test was prepared to be used as a pre-posttest. It was pre used to identify the actual level of the students concerning the EFL creative reading skills before administering the metamemory based-program. As a post test, it was used to investigate using the metamemory-based program in developing the creative reading skills.

\section{2- Constructing of the creative reading test}

The test was designed in the light of the following sources :( a-reviewing related studies concerned with designing EFL creative reading tests, $b$-the creative reading skills identified by the results of the questionnaire of the creative reading skills. 


\section{3- Description of the creative reading test}

The test consists of eight items. The total score is sixteen; two marks for each question. The skill (Personalizing natural phenomena by using as many personal qualities as possible was measured by question one: Personalize the second frog by using as many personal qualities as possible. The skill (Mentioning all the characteristics of someone or something to express opinions) was measured by Question two: What are the main characteristics of the first frog. The skill (Suggesting different titles for a story) was measured by question three: Suggest different titles for the story. The skill (Producing various questions about information that is not directly mentioned in the text) was measured by Question four: Suggest various questions the second frog should ask to the first frog. The skill (Thinking reflectively to generate more ideas for interest or clarity) was measured by Question five: Present a dialogue between the two frogs. The second elaboration skill (Imaging herself a character in a story to enhance the ideas) was measured by question six: Imagine yourself in this trouble, what is the best solution?. The skill (Suggesting new ends or conclusions for a story) was measured by Question seven: Suggest an end or conclusion for the story. The skill ( Giving new strange names to characters of a story) was measured by question eight: Give new strange names to each frog

\section{4- Validity of the creative reading test}

To measure the validity of the test content, the test was submitted to EFL specialists to evaluate the test as a whole in terms of content, number of questions, correctness, level of comprehension and time limits. The test proved to be valid. The test validity was determined and estimated according to the following formula:

$$
\text { Test validity }=\sqrt{\text { reliability }}
$$

It was (0.94) and this indicated that it was valid.

\section{5-Reliability of the creative reading test}

The test was administered to a group of students, not included in the participating groups. Formula of Cronbach's 
Alpha was used to calculate the coefficient of reliability. Cronbach's Alpha $=0.89$ ). This indicated that the test was reliable.

\section{6-Piloting the creative reading test}

The aims of piloting the test were (a- timing the test, bdetermining the difficulty of the questions included in the test.

-Participants in the test piloting

Forty students, other than the participants of the study, were selected randomly for piloting the test.

-Results of piloting the test

The results of piloting the test showed that the test is suitable for secondary school students.

\section{-Test time}

It was estimated that a period of thirty minutes (nearly four minutes for each question) would provide ample time for the students. This period was estimated as follows

$\frac{25+35}{2}=\frac{60}{2}=30$ minutes

25 is the period taken by the fastest student. 35 is the period taken by the slowest one

\section{C- The EFL Creative Reading Rubric}

\section{1-Purpose of the EFL creative reading rubric}

The main purpose of the rubric is to be used as a post requisite for the EFL creative reading test

\section{2-Construction of the rubric}

The rubric was constructed after reviewing literature related to the area of EFL creative reading skill and its assessment.

\section{3-Description of the rubric}

The rubric includes scales for the components of the EFL creative reading skill (fluency, flexibility, elaboration and originality). Each component has five rating scales (outstanding, above expectation, satisfactory, below expectations, unsatisfactory). Every student should be given four scores for the outstanding level, three scores for the above-expectations level, two scores for the satisfactory level, one score for the belowexpectations level or zero for the unsatisfactory level. 


\section{4-Validity of the rubric}

To make sure that the rubric is valid for its purpose, it was administered to jury members to determine its validity according to the suitability to secondary school students and measuring the targeted EFL creative reading skills. The jury members approved the rubric, but some of them supposed to say not only "the student is sometimes able to generate a large number of ideas, but also "the student can master two or one of the two skills to generate a large number of ideas". Using only the first sentence is misleading.

\section{3-The study material}

\section{The metamemory based program}

The following is a description of the steps the researcher went through to design the current metamemory based-program for the EFL secondary school students:

\section{Content of the metamemory based program}

The program consists of ten stories. Each story ends with a song which crystalized the main idea of the story. The stories are taken from the following websites:

http://www.marcandangel.com/2013/05/21

http://www.thelivingtreasure.com/forum/

http://www.goal-setting-for-success.com/

http://www.videoinspiration.net/blog/

The songs (with lyrics) that are included in the program are: "Smile" by Michael Jackson, "You are my life" by Michael Jackson, "Count on me" by Bruno Mars, "Hero" by Mariah Carey, "I want to spend my life loving you" by Antonio Banderas and Catherine Jones, "Honesty by Misswelton ,"Will you be there" by Michael Jackson, "I can't smile without you" by Barry Manilow, "When you believe" by Whitney Houston, and a piece of prose about the value of time, from the website:https://www.youtube.com/watch?v=oquY8qnneVk

\section{Procedures and duration of the metamemory based-program}

The creative reading pre test was administered to the participants on the fourteenth of February 2016. The first session of the program started on the sixteenth of February 2016. The metamemory based-program consisted of ten stories, nine songs 
and a piece of prose. The whole program consisted of twenty sessions. Each story and song took two sessions a week to enable the students to develop their EFL creative reading skills. While using every story and related song, the first session was dedicated to the evaluation of mastering the target skills. Every session took nearly forty minutes a day. The experiment took a term. The experiment ended on the nineteenth of April 2016, and then followed by administering the EFL creative reading test on the twenty first of April 2016.

\section{Data analysis and the results}

The first hypothesis stated that "there is a statistically significant difference between the mean scores of the experimental group and the control group in their performance of the post EFL creative reading test in favor of the experimental group". To validate this hypothesis, independent samples t-test was used. The following table indicates the results of the post administration of the EFL creative reading test to the experimental and control groups

\begin{tabular}{|c|c|c|c|c|c|c|}
\hline The group & $\begin{array}{l}\text { The } \\
\text { creative } \\
\text { reading }\end{array}$ & $\mathrm{N}$ & Mean & $\begin{array}{c}\text { Std. } \\
\text { devia } \\
\text { tion }\end{array}$ & Ttvalue & Sig. \\
\hline $\begin{array}{l}\text { Experimental } \\
\text { group }\end{array}$ & \multirow{2}{*}{ Fluency } & 35 & 3.34 & .59 & \multirow{2}{*}{12.73} & \multirow{2}{*}{0.0} \\
\hline Control group & & 35 & 1.60 & .55 & & \\
\hline $\begin{array}{l}\text { Experimental } \\
\text { group }\end{array}$ & \multirow[t]{2}{*}{ Flexibility } & 35 & 3.25 & .65 & \multirow[t]{2}{*}{11.13} & \multirow[t]{2}{*}{0.01} \\
\hline Control group & & 35 & 1.57 & .60 & & \\
\hline $\begin{array}{l}\text { Experimental } \\
\text { group }\end{array}$ & \multirow{2}{*}{ elaboration } & 35 & 3.14 & .64 & \multirow{2}{*}{10.62} & \multirow{2}{*}{0.01} \\
\hline Control group & & 35 & 1.54 & .61 & & \\
\hline $\begin{array}{l}\text { Experimental } \\
\text { group }\end{array}$ & \multirow[t]{2}{*}{ Originality } & 35 & 3.17 & .66 & \multirow[t]{2}{*}{8.48} & \multirow[t]{2}{*}{0.01} \\
\hline Control group & & 35 & 1.68 & .79 & & \\
\hline $\begin{array}{l}\text { Experimental } \\
\text { group }\end{array}$ & \multirow[t]{2}{*}{ Total } & 35 & 12.88 & 1.8 & \multirow[t]{2}{*}{15.59} & \multirow[t]{2}{*}{0.01} \\
\hline Control & & 35 & 6.34 & 1.6 & & \\
\hline
\end{tabular}


The second hypothesis stated that "there is a statistically significant difference between the mean scores of the experimental group in their performance of the pre and post administrations of the EFL creative reading test in favor of the post administration". The following table compares the pre and post administrations

\begin{tabular}{|c|c|c|c|c|c|c|}
\hline $\begin{array}{l}\text { The creative } \\
\text { reading test }\end{array}$ & The skills & $\mathbf{N}$ & Mean & $\begin{array}{c}\text { Std. } \\
\text { deviation }\end{array}$ & $\begin{array}{c}\text { t } \\
\text { value }\end{array}$ & Sig. \\
\hline $\begin{array}{l}\text { Pre creative } \\
\text { reading test }\end{array}$ & \multirow{2}{*}{ Fluency } & 35 & 1.571 & .65 & \multirow{2}{*}{24.59} & \multirow{2}{*}{0.01} \\
\hline $\begin{array}{l}\text { Post creative } \\
\text { reading test }\end{array}$ & & 35 & 3.34 & .59 & & \\
\hline Pre test & \multirow{2}{*}{ Flexibility } & 35 & 1.628 & .68 & \multirow[b]{2}{*}{17.61} & \multirow[b]{2}{*}{0.01} \\
\hline Post test & & 35 & 3.25 & .65 & & \\
\hline Pre test & \multirow{2}{*}{$\begin{array}{c}\text { elaboratio } \\
n\end{array}$} & 35 & 1.57 & .60 & \multirow{2}{*}{18.51} & \multirow{2}{*}{0.01} \\
\hline Post test & & 35 & 3.14 & .64 & & \\
\hline Pre test & \multirow{2}{*}{ Originality } & 35 & 1.51 & .56 & \multirow{2}{*}{20.35} & \multirow{2}{*}{0.01} \\
\hline Post test & & 35 & 3.17 & .66 & & \\
\hline Pre test & \multirow[t]{2}{*}{ Total } & 35 & 6.314 & 1.69 & \multirow[t]{2}{*}{49.9} & \multirow[t]{2}{*}{0.00} \\
\hline Post & & 35 & 12.8 & 1.85 & & \\
\hline
\end{tabular}

The first table indicates that the experimental group surpassed the control group in the post administration of the EFL creative reading test as a whole and its sub skills (fluencyflexibility- elaboration- originality). According to this result, the first hypothesis was accepted. The second table shows that the experimental group did better in the post administration of the creative reading test as a whole and its sub skills (fluency, flexibility, elaboration, originality) than in the pre administration. Thus the second hypothesis was accepted. 


\section{Discussion of the results}

The results of the current study verified that the two hypotheses. These significant improvements and modifications can be attributed to a number of causes related to the nature of the metamemory based program. Learning English in rural schools in Egypt has always been a major problem for educators. The language is almost non-existent other than the few periods of English per week for learners. The selected material (stories and songs) was a new experience for these rural students. They felt motivated to read creatively. It is the first time for these students to listen to authentic songs by famous singers like Whitney Houston and Michael Jakson. Consequently, their motivation, confidence and effort were boosted to learn more. The students were reluctant to read and do much effort. After being participants in the metameory based program, they became enthusiastic to read and do much effort using the selected metamemory activities to become creative readers. Some metamemory activities are used to develop creative reading skills such as preparing and planning for learning use it before you lose it, making lists, previewing, visualization, role play, activation of prior knowledge, simulation, telling a story, using photographs and illustrations, questioning, acronyms, surveying, thinking aloud, prediction, concept maps, games. Using these metamemory activities enabled the students to master the EFL creative reading skills.

\section{Conclusions:}

In terms of the study achieved results and given the above mentioned interpretation and discussion, it can be concluded that the meta-memory based program proved to be efficient in developing EFL creative reading skills. The students succeeded to master the two fluency skills: (Personalizing natural phenomena or things by using as many personal qualities as possible and mentioning all the characteristics of someone or something to express opinions). Also, the students had become creative readers after mastering the two flexibility skills (aSuggesting different titles for a story and b- producing various questions about information that is not directly mentioned in the

$$
r \cdot r
$$


text). The metamemory based program enabled the EFL secondary school students to generate more details for enhancing the ideas while practicing the two elaboration skills (Thinking reflectively to generate more ideas for interest or clarity and imaging herself a character in a story to enhance the ideas). After being trained to use metamemory activities, the students managed to generate novel ideas while suggesting new conclusions to the story and giving new strange names to characters in the stories. The students mastered the originality skills. All this success in creative reading can be attributed to training to use some effective metamemory activities before, during and after reading creatively.

\section{Recommendations}

In the light of the results and conclusions of the present study, the researcher presented the following recommendations:

1- The EFL creative reading skills should be allocated more space in the textbook and timetable.

2- EFL teachers have to encourage creativity while reading in English as a foreign language through providing appropriate and interesting materials.

3- Utilizing the metamemory activities for developing creative skills while learning English as a foreign language.

4- EFL teachers should be trained to the implementation of metamemory activities so as to develop creative reading skills among their students.

5- Syllabus designers and textbook writers should design more effective textbooks and teachers' guides with the focus on the instruction of metamemory activities.

\section{Suggestions for further research}

The following areas are suggested to further research

1- More researches are needed to provide effective strategies for developing the EFL creative reading skills. That is because the area of research is, though important, still under research.

2- It will be of value if other researchers design in-service training programs for EFL teachers to help these teachers develop the creative reading skills among their students.

$$
r \cdot \varepsilon
$$


3- More researches are needed to investigate using metamemory activities in developing the EFL listening, speaking, grammar structures and vocabulary acquisition.

4- Future studies may be done to identify the relationship between metamemory activities and other psychological factors such as motivation, self-efficacy, anxiety, creativity and leaner's beliefs.

5- More researches are needed to adopt metamemory activities in teaching English as a foreign language for other categories of learners such as students with learning difficulties, visual impairments or hearing impairments.

\section{References}

1-Abdul Latif, O. (2006) The Effect of Training First Year English Majors of the Faculty of Education in Integrating Creative Reading and Writing Skills on their Performance in these Skills. Unpublished M. A. thesis. Minia University.

2-Amiri, B. and Ghiassi, S. (2012) The Impact of Teaching Procedural Metamemory Strategies on EFL Learners' Reading Comprehension. Journal of Language and Translation. Vol. 3. N. 1. Pp. 51-60.

3-Arts Council (2009) The Future of Reading: A Public Value Project. Creative Research. Broadway. London . England.

4-Christensen, T. (2013) How Creativity, Memory, And DEJAVU Really Work. http://creativesomething.net/post

5-Dachis, A. (2012) Boost Your Creativity by Improving Your Working Memory. Available at http:// lifehacker.comboostyour-creativity-by-improving-your-workingmemory

6-Gaultney, J. (1992) The effect of prior knowledge and metamemory on the acquisition of a reading comprehension strategy. Unpublished Ph.D. thesis. Florida Atlantic University. United States.

7-Holden, J. (2004) Creative Reading. Young People, Reading and Public Libraries. London. Elizabeth House.

8-Karably , K. and Zabrucky , K. ( 2009) Children's metamemory: A review of the literature and implications for 
the classroom. International Electronic Journal of Elementary Education. Vol.2, N.1. Pp. 32- 52

9-Masoud,E. (2014) The Effectiveness of Higher-Order Questioning Techniques in Developing EFL Creative Reading Skills among secondary School students. Unpublished M.A. thesis. Menoufiya University.

10-Moharam, H. (1997) The Effect of Using the Discussion Method on Developing First-Year Faculty of Education English Majors' Reading Comprehension and Creative Reading_Skills. Unpublished M.A. thesis. Minia University.

11-Montgomery, J. ( 2003) Working memory and comprehension in children with specific language impairment: what we know so far. Journal of Communication Disorders. Vol. 36. Pp. 221-231. Available online at www.sciencedirect. Com.

12-Moorman, K. and Ram, A. (1994) Integrating Creativity and Reading: A Functional Approach. In Proceedings of the 16th Annual Cognitive Science Conference, Atlanta, GA, August 1994. Available at www.cc.gatech.edu

13-Numminen, H. (2002) Working memory in adults with intellectual disability. Famr, Research Publications. Helsinki: Kehitysvammaliitto.__ Available at http://papunet.net/selkokeskus/

14- Rodirguez, A. (2012) Graduate Students' Reflections on Transformative Education for Latino Students. University of Texas at Brownsville.

15-Sawyer, K. (2013) The Creative Power of Memory. htt:// www.huffingtonpost com.

16-Shu-Chi, Y. and Tun-whei, C. (2009) The Effect of MTI on L2 Proficiency and Learning Strategies. The Asian EFL journal.Vol.11. N. 3. Pp.9-28.

17-Tran, V. (2013) 19 New Tips Teach People How to Improve Memory Retention. Available at: file:///F:/7-metamemory+ $\% 20$ efl $\%$

18-Van Blerkom, D.(2009) College Study Skills: Becoming a strategic learner. Boston: Wadsworth-Cengage.

$$
r \cdot 1
$$




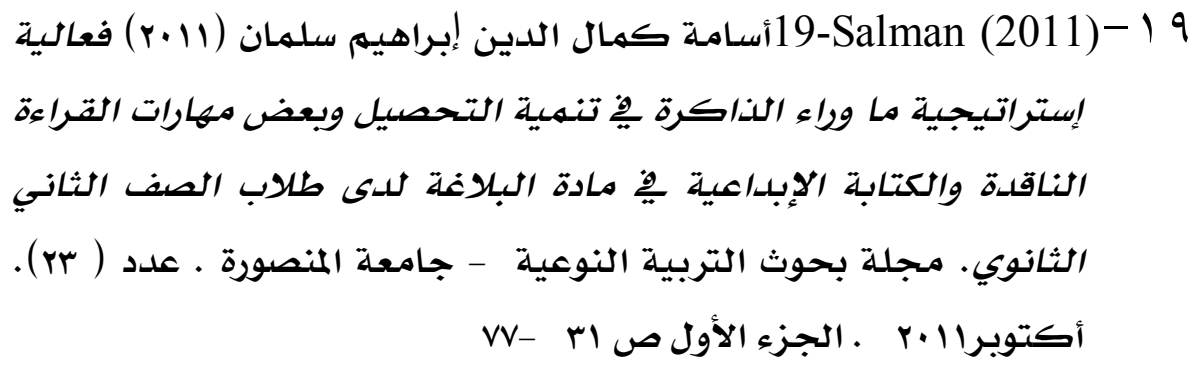

Appendix (1) The creative reading skills questionnaire

\begin{tabular}{|c|c|c|c|c|}
\hline $\begin{array}{l}\text { The } \\
\text { creative } \\
\text { reading } \\
\text { skill }\end{array}$ & The creative reading sub skills & $\begin{array}{c}\text { Very } \\
\text { important }\end{array}$ & important & $\begin{array}{c}\text { Less } \\
\text { important }\end{array}$ \\
\hline $\begin{array}{l}\text { The } \\
\text { fluency } \\
\text { skills }\end{array}$ & $\begin{array}{l}\text { 1-Personalizing natural } \\
\text { phenomena or things by using as } \\
\text { many personal qualities as } \\
\text { possible } \\
\text { 2- Mentioning all the } \\
\text { characteristics of someone or } \\
\text { something to express opinions. }\end{array}$ & & & \\
\hline $\begin{array}{c}\text { The } \\
\text { flexibility } \\
\text { skills }\end{array}$ & $\begin{array}{l}\text { 1- Suggesting different titles for } \\
\text { a story. } \\
\text { 2- Producing various questions } \\
\text { about information that is not } \\
\text { directly mentioned in the text. }\end{array}$ & & & \\
\hline $\begin{array}{l}\text { The } \\
\text { elaborate- } \\
\text { ion skills }\end{array}$ & $\begin{array}{l}\text { 1- Thinking reflectively to } \\
\text { generate more ideas for interest } \\
\text { or clarity. } \\
\text { 2- Imaging himself/herself a } \\
\text { character in a story to enhance } \\
\text { the ideas. }\end{array}$ & & & \\
\hline $\begin{array}{l}\text { The } \\
\text { original-ity } \\
\text { skills }\end{array}$ & $\begin{array}{l}\text { 1-Suggesting new ends or } \\
\text { conclusions for a story } \\
\text { 2- Giving new strange names to } \\
\text { characters of a story }\end{array}$ & & & \\
\hline
\end{tabular}

Appendix (2)The EFL Creative Reading Test

Read the following story then answer the following questions

Once upon a time, there were two frogs which fell into a cream can. They swam around for a while, discussing the fact that it would be nearly impossible to get out of 
their predicament. The first frog said "Why I'm being in this trouble? Why? So let me just cry". The second frog said "No pain, no gain. I should try again and again". The first frog

1- Personalize the second frog by using as many personal qualities as possible.

2- What are the main characteristics of the first frog? Express your opinion.

3-Suggest different titles for the story.

4- Suggest various questions the second frog may ask to the first frog.

5- Present a dialogue between the two frogs

6- Imagine yourself in this trouble, what are the best solutions?

7- Suggest an end or conclusion for the story.

8- Give new strange names to each frog. 


\section{Appendix (3) The EFL creative reading rubric}

\begin{tabular}{|c|c|c|c|c|c|c|}
\hline $\begin{array}{l}\text { Compon- } \\
\text { ents of } \\
\text { creat-ive } \\
\text { readi-ng } \\
\text { skill } \\
\downarrow\end{array}$ & $\begin{array}{l}\text { Rating } \\
\text { scal-e } \rightarrow\end{array}$ & $\begin{array}{l}\text { Outstan } \\
\text {-ding } \\
(4)\end{array}$ & $\begin{array}{l}\text { Above } \\
\text { expecta- } \\
\text { tion } \\
(3)\end{array}$ & $\begin{array}{c}\text { Satisfactor } \\
\mathbf{y} \\
(2)\end{array}$ & $\begin{array}{c}\text { Below expecta- } \\
\text { tions } \\
(1)\end{array}$ & $\begin{array}{l}\text { Unsatisfa- } \\
\text { ctory } \\
(0)\end{array}$ \\
\hline \multicolumn{2}{|c|}{ Fluency } & $\begin{array}{l}\text { The } \\
\text { student } \\
\text { always } \\
\text { masters } \\
\text { the two } \\
\text { fluency } \\
\text { skills. }\end{array}$ & $\begin{array}{l}\text { The student } \\
\text { usually } \\
\text { masters the } \\
\text { two fluency } \\
\text { skills. }\end{array}$ & $\begin{array}{l}\text { The student } \\
\text { sometimes } \\
\text { masters the } \\
\text { two or one } \\
\text { of the } \\
\text { fluency } \\
\text { skills. }\end{array}$ & $\begin{array}{l}\text { The student } \\
\text { hardly ever } \\
\text { masters one of } \\
\text { the following } \\
\text { two fluency } \\
\text { skills. }\end{array}$ & $\begin{array}{l}\text { The } \\
\text { student } \\
\text { never } \\
\text { masters } \\
\text { any of the } \\
\text { two } \\
\text { fluency } \\
\text { skills. }\end{array}$ \\
\hline \multicolumn{2}{|c|}{ Flexibility } & $\begin{array}{l}\text { The } \\
\text { student } \\
\text { always } \\
\text { masters } \\
\text { the two } \\
\text { flexibilit } \\
\text { y skills }\end{array}$ & $\begin{array}{l}\text { The student } \\
\text { usually } \\
\text { masters the } \\
\text { two } \\
\text { flexibility } \\
\text { skills }\end{array}$ & $\begin{array}{l}\text { The student } \\
\text { sometimes } \\
\text { masters one } \\
\text { or two of } \\
\text { the } \\
\text { flexibility } \\
\text { skills }\end{array}$ & $\begin{array}{c}\text { The student } \\
\text { hardly ever } \\
\text { masters one of } \\
\text { the two } \\
\text { flexibility skills. }\end{array}$ & $\begin{array}{c}\text { The } \\
\text { student } \\
\text { never } \\
\text { masters } \\
\text { any one of } \\
\text { the two } \\
\text { flexibility } \\
\text { skills. }\end{array}$ \\
\hline \multicolumn{2}{|c|}{ Elaboration } & $\begin{array}{l}\text { The } \\
\text { student } \\
\text { always } \\
\text { masters } \\
\text { the two } \\
\text { elaborati } \\
\text { on skills }\end{array}$ & $\begin{array}{l}\text { The student } \\
\text { usually } \\
\text { masters the } \\
\text { two } \\
\text { elaboration } \\
\text { skills }\end{array}$ & $\begin{array}{l}\text { The student } \\
\text { sometimes } \\
\text { masters one } \\
\text { or two of } \\
\text { the } \\
\text { elaboration } \\
\text { skills. }\end{array}$ & $\begin{array}{l}\text { The student } \\
\text { hardly ever } \\
\text { masters one of } \\
\text { the two } \\
\text { elaboration } \\
\text { skills. }\end{array}$ & $\begin{array}{l}\text { The } \\
\text { student } \\
\text { never } \\
\text { masters } \\
\text { any one of } \\
\text { the two } \\
\text { elaboratio } \\
\text { n skills. }\end{array}$ \\
\hline \multicolumn{2}{|c|}{ Originality } & $\begin{array}{l}\text { The } \\
\text { student } \\
\text { always } \\
\text { master } \\
\text { the two } \\
\text { originali } \\
\text { ty skills. }\end{array}$ & $\begin{array}{l}\text { The student } \\
\text { usually } \\
\text { masters the } \\
\text { two } \\
\text { originality } \\
\text { skills. }\end{array}$ & $\begin{array}{l}\text { The student } \\
\text { sometimes } \\
\text { masters one } \\
\text { or two of } \\
\text { the } \\
\text { originality } \\
\text { skills. }\end{array}$ & $\begin{array}{l}\text { The student } \\
\text { hardly ever } \\
\text { masters one of } \\
\text { the two } \\
\text { originality } \\
\text { skills. }\end{array}$ & $\begin{array}{l}\text { The } \\
\text { student } \\
\text { never } \\
\text { masters } \\
\text { any one of } \\
\text { the two } \\
\text { originality } \\
\text { skills. }\end{array}$ \\
\hline
\end{tabular}

